Kirwan, E. O'G.- "Epidemic Superficial Punctate Keratitis in Bengal." Prcc. All-India Ophthal. Soc., Vol. III, p. 1, 1933.

Kuchner, K.- "Inoculations with Herpes Virus." Klin. Monatsbl. f. Augenheilk., Vol. XCI, p. 485, 1933.

Lloyd, R. I.- "Herpes and Allied Conditions." Amer. Jl. of Ophthal., Vol. XIV, p. 601,1931

Moore, R. F - "Ocular Manifestations of Lesions of the Fifth Nerve." British Medical Association Centenary Meeting. Brit. Med. Jl., July, 1932.

Ochapovski and Lipovski.- "Pathology of the Cornea ; Herpetic Keratitis." Sovietskii Viestriek. Ophtal., Vol. V, part 2, p. 109, 1934. (R. K. Daily, abstract in Amer. Jl. of Ophthal., Vol. XVIII, p. 191, 1935).

Rokitskaja. - "Aetiology and Pathogenesis of Herpes Zoster Ophthalmicus." Sovietskii Viestriek. Ophtal., Vol. VI, part 4, p. 453, 1935. (Abstract in Amer. Jl. of Ophthal, 1935).

Sandomir.- " Two Cases of Disciform Keratitis." Sovietskii Viestriek. Ophtal., Vol. VI, part 3, p. 411, 1935. (Abstract in Amer. Jl. of Ophthal., 1935).

Schieck, F.- "Kurzes Handbuch für Ophthal.

Szekely, J.- "Keratitis nummularis Dimmer." Graefe's Arch.f. Ophthal., Vol. CXXXIV, p. 184, 1935.

Vogt.-Slit-lamp Micrcscopy of the Living Eye. Second Edition.

Verhoeff.- " The Pathology of Keratitis Punctata Superficialis with Remarks on Neuropathic Keratitis." Arch. of Ophthal., Vol. XL, p. 486, 1911. (Quoted by Doggart, v. supra).

Wright.- "Superficial Punctate Keratitis." Brit. Jl. of Ophthal., Vol. XIV, p. $595,1930$.

\title{
BACTERIOLOGICAL AND EXPERIMENTAL RESEARCHES ON THE AETIOLOGY OF TRACHOMA
}

\author{
BY \\ Drs. A. CUÉNOD and R. NATAF \\ TUNIS
}

In the course of experimental researches on trachoma, commenced by one of us in collaboration with Charles Nicolle more than thirty years ago, and continued with him until 1922, important results were arrived at with regard to the experimental transmission of trachoma. We have shown that there is an infecting virus, and we have given its principal physiological characteristics, notably those of its filterability and of its long conservation in the testicle of the living rabbit ${ }^{1}$.

Does this virus which has been demonstrated physiologically and experimentally always remain invisible morphologically? Charles Nicolle, essentially an experimental physiologist, expressed an opinion on this point, which we as practising clinicians always ask ourselves, anxious as we are to have a sign, exact,

Note by translator, Mr. A. F. MacCallan :-It will be remembered that Cuénod was associated for many years with that distinguished director of the Pasteur Institute of Tunis, Charles Nicolle, in experimental pathological work on trachoma. This translation has been approved by the authors. 
casily demonstrable and rapid, which is pathognomonic of that protean condition, trachoma.

Having got as far as this our researches at the Institut Pasteur de Tunis ceased, and our attention was directed to clinical matters such as the symptomatology, the treatment, the prophylaxis and especially the biomicroscopy of the conjunctiva. However we did not lose sight of the aetiological problem, and in 1929 in a paper entitled "Ultra-virus and Trachoma" we put forward various hypotheses which now seem to be confirmed ${ }^{2}$.

It was the epoch of the remarkable researches of Charles Nicolle with regard to the louse and its relation to the propagation of exanthematous typhus; an epoch when important work from various sources on the Rickettsias appeared, which from the beginning were much discussed by Nicolle himself.

It being agreed that trachoma flourished under the same conditions as exanthemic typhus, and that the two nosographical charts of their world incidence were practically identical, it occurred to us, and we spoke of it more than once to Charles Nicolle, that the louse and the Rickettsias bore some relation to trachomatous infection, and we are working on these lines.

This theory of an infection by Rickettsias occurred also to Busacca in Brazil, where important researches on typhus and the Rickettsias were being carried out under the direction of RochaLima $^{3}$. Busacca's publications ${ }^{4}$ antedated ours, and we are glad that we have not been alone in this somewhat bold hypothesis.

However we have been carrying out our investigations in our own laboratory on staining methods, etc. We find constantly certain tiny bodies, which stain feebly, in the protoplasmic débris, of which certain parts of trachomatous scrapings are full, we consider that this protoplasmic débris, which is more abundant in trachoma than in any other conjunctival affection, has some significance due to a special action of the trachoma virus, and that further research in this direction should be pursued.

A careful examination of Giemsa-stained trachoma follicles leads to the following conclusions :-

(1) There is degeneration of the large mononuclear cells, known as epithelioid cells.

(2) Lysis of the cytoplasm of these cells.

(3) The presence of tiny granular dots $(0 \cdot 2$ to $0.5 \mu)$ which are very special and very characteristic in the cytoplasm, which may be adherent to the nucleus, or if this no longer exists may be present as débris in its neighbourhood.

(4) The same dots are present in the protoplasm of epithelial cells as Halberstaedter-Prowaczek inclusions.

5. These granular dots may be found in a free state. 
In view of the importance attached to the protoplasmic débris mentioned above we have given them the name of "plastilles" or little drops of plasma.

The existence of the dots just spoken of is undoubted, but it is difficult even with a high magnification to appreciate their exact shape; they are sometimes round, sometimes ovoid, sometimes in the shape of dumb-bells, sometimes filamentous, but always extremely small and at the extreme limit of visibility.

These corpuscles present analogies with the epithelial inclusions of Halberstaedter-Prowaczek, their staining property varies, they possess little of the refractive quality of the ordinary bacteria, and it is impossible to cultivate them on the usual media. Nor do they resemble in any way either the ordinary protoplasmic condensations or the "mitochondries."

Our first communication on these matters was made in Paris in May, 1934, at a meeting of the La Ligue contre le Trachome, at which were present the eminent trachomatologists Morax, MacCallan, Bailliart, Pagés, etc. This was given orally and was received with kindly scepticism.

Eliminating possible sources of error we published preliminary notes on the subject at the beginning of 1935 , thanks to Nicolle and de Lapersonne ${ }^{5}$. We confirm our findings of 1934. We insist on the importance of the destruction of the cytoplasm of the epithelioid cells; we believe that the crumbling of the perinuclear protoplasm of these cells is not due to the bursting of the follicles when their contents are removed but to a real preliminary lysis caused by the specific virus of trachoma. We also insist on the presence of the dots to be seen in the débris, with the hypothesis which the result of our researches has fully confirmed, that we have to do with foreign bodies, very minute, about which the condensed protoplasm makes their contour and shape difficult to appreciate.

In a second paper ${ }^{6}$ we spoke of the use of " cyanochine," which gives a negative colouration to the micro-organisms which appear clear on a blue-violet back-ground. Trachomatous scrapings stained with cyanochine are very instructive, the infra-microorganisms generally appear separated from their matrix of plastine, and in considerable numbers; the illustration given in the Archives d'Ophtalmologie shows this well, but it would have been still better if we had been able to give it in colour.

Our third paper $^{7}$ gave sections of follicles, stained with Giemsa, with a short description. These sections show epithelial cells with Halberstaedter-Prowaczek inclusions, and epithelioid cells with hypertrophied nuclei around which innumerable Rickettsian bodies abound. A certain number of nuclei in the interior of the follicles, 
like the inclusion cellules of the epithelium, are capped by a dark hood made up of Rickettsias, agglomerated together and embedded in plastine. These are not the ordinary mastzellen, as one might think; the description we have given is quite new and full of interest; they are parasitic cells.

In a fourth note ${ }^{8}$ we described our early researches and we have shown $(a)$ the infection of laboratory-bred lice, which are free from intestinal parasites, by trachomatous material, and the obtainment of real cultures in vivo of Rickettsias in their intestines ; and $(b)$ experimental infection of the monkey (singe or Barbary ape) by these same cultures.

Since then we have repeated these experiments while varying their details; we have made multiple passages and crossed from louse to louse, from the louse to the guinea-pig's testicle and viceversa; in all these experiments the result has been positive morphologically, as well as experimentally by constant bacteriological control and by the inoculation of Barbary apes (magot).

As an example of our experimental researches the details of one of them is given here.

Inoculation of the infected testicle of a guinea-pig into the intestine of a louse, and after several passages into the Barbary ape (singe).

On December 22, 1936, M. C. D., a boy twelve years of age, was brought by his father to the clinic in the Rue Zarkoun, Tunis. He had trachoma in the second stage, which had not been treated, and there was no superimposed bacterial conjunctivitis. There were voluminous follicles on the tarsal and retrotarsal conjunctiva. The same day at the Institut Pasteur de Tunis abundant trachomatous material was obtained from the boy by puncture with a Graefe knife. This was pounded up in a little normal saline solution and immediately injected into the left testicle of guinea-pig, number 82 . The following days there was no fever, no tenderness and no appreciable swelling.

On the seventh day, December 29, the gland was punctured and a very small quantity of rose-coloured serum drawn off in a syringe. This was stained with Giemsa and with cyanochine; it showed testicular cells, numerous mononuclear cells with the protoplasm in a state of lysis and others fairly large with the cytoplasm crammed with Rickettsia-like dots and with plastilles in morula-form which were full of dot-like bodies analogous to those described in trachoma.

Here, as in trachoma follicles, the Rickettsia-like bodies are crowded together and glued up in a thick plastine which increases their volume and makes their contour indefinite, so that they are often difficult to distinguish. 
On December 30 the animal was killed and with the pulp of the crushed testicle 80 laboratory-bred lice were inoculated. On January 7, 1937, a number of these lice were examined; obvious Rickettsias in great abundance were found in their intestines when stained with cyanochine and azure (slides 70,71 and $72 \mathrm{C}$ bis).

The remaining lice were used for passage from louse to louse, and from these, new passages were made during the month of January. On February 2 with lice which had been infected on the sixth positive passage we inoculated the Barbary ape (magot), Xero, in the right eye by scarification, and in the left eye by subconjunctival injection.

On February 13 obvious follicles on the thickened conjunctiva of the retro-tarsal region of both eyes could be seen. On March 4 the follicles in the upper fornix had increased and had amalgamated; in the lower lid numerous follicles were seen and the caruncle was swollen and invaded.

On March 16. a new Barbary ape (magot number M. 97) was inoculated with a scraping from Zero, which like Xero had no spontaneous follicles, the inoculum showed numerous Rickettsias.

Our experiments are being continued, but it seems logical to conclude that the Rickettsia were not merely present, but that they were the real agents of trachomatous infection, since the results obtained in the case of Xero were obtained first by passage through the guinea-pig's testicle but also by six passages through the intestines of lice.

Human inoculation with lice infected by the Rickettsia of trachoma. We summarize here a description of the experiment which we consider to be a definite clinical and scientific proof of the part played by Rickettsia in trachoma.

We have actually succeeded in producing in man a manifest trachoma by inoculating with lice, infected by trachoma virus, the healthy conjunctiva of an eye which had been blinded by a former injury.

A brood of laboratory-bred lice, which had been shown to be free from intestinal parasites, was inoculated with trachomatous material. After several days these lice showed an undoubted and abundant growth of the Rickettsia of trachoma. Their intestines were pounded up and inoculated by scarification and massage into the conjunctiva of a man's eye ; this eye was blind as the result of a former injury, and the conjunctiva had been examined beforehand and shown to be quite healthy, clinically, biomicroscopically and bacteriologically.

At the end of eight days, without any discharge or other sign of inflammation the first crop of follicles appeared, which gradually became generalised throughout the tarsal and supra-tarsal conjunctiva. 
At the end of two months the appearance was unmistakable and showed all the characteristics of trachoma, clinical, microscopical and biomicroscopical.

The tears and ocular secretions were examined daily, and from the eighth day after the inoculation we noted the presence of epithelial cells containing Halberstaedter-Prowaczek Körperchen. Later the Rickettsia-like dots gradually appeared and could be found scattered in the protoplasm of the epithelial cells, lying on the epithelioid cells and plastilles, as well as in the free state.

These findings lead to the conclusion that trachoma is an epitheliosis, the Rickettsia infecting first the epithelial cells, and then becoming scattered throughout the other cellular elements.

The details of our experiments are published elsewhere ${ }^{13}$.

We believe that we are the first to have obtained similar results. What is new is to have cultured in vivo in the intestines of the louse and in the testicle of the guinea-pig the Rickettsias which are found in trachoma follicles. We think that as the result of our reinoculation of the Barbary ape (singe) we have established their importance in the aetilogy of trachoma.

Busacca in Brazil ${ }^{9}$ and v. Szily in Germany ${ }^{10}$ have inoculated with trachomatous material various organs of animals in the laboratory, especially the vitreous of the rabbit. They have obtained very interesting lymphocytic deposits, but Busacca who had found Rickettsias in the tunica vaginalis of guinea-pigs and in rabbits, which had been previously inoculated failed to find them in the vitreous, while v. Szily did not look for them.

Poleff's very interesting experiments in Morocco are confirmatory of ours ${ }^{11}$. He is an expert in cellular cultures (Carrel) and obtained abundant cultures in vitro of trachoma Rickettsias, and could again find them in inoculated animals, such as the rabbit, the guinea-pig and the fowl.

\section{Summary}

My first researches were made in $190 \tau$ at Tunis. They have established that trachoma is a contagious disease, caused by a virus the principal characters of which have been described above.

Under the influence of researches on typhus and on the Rickettsias in various bacteriological centres, and especially at the Institut Pasteur de Tunis, bacteriological and experimental researches have been made showing that the trachomatous virus has a close relationship with an infra-organism of the Rickettsia family, the presence of which is morphologically demonstrable, as Busacca as well as ourselves has pointed out.

The anal inoculation of the louse with trachomatous material causes the rapid increase of this organism. After many passages 
it is still able to reproduce lesions characteristic of trachoma on the conjunctiva of the Barbary ape (singe) and of man ${ }^{12}$.

Therefore it seems to be proved that trachoma is due to an infection of the conjunctiva with Rickettsias, these being the active principle of the trachomatous virus.

We consider that we have proved both morphologically and experimentally that trachoma is a Rickettsiosis, and that the louse forms a reservoir, and is perhaps one of the vectors of trachomatous virus, and probably the principal one.

\section{REFERENCES}

1. Ch. Nicolle and A. Cuénod.-Opt. Roy. Acad. Ges. Sciences, Paris. March 6, 1907 ; March 29, 1911 ; July 16, 1912 ; April 14, 1913; December 8. 1919 ; March 15, 1920 ; April 25, 1921.

2. A. Cuénod and R. Nataf.-Rev. Internat. du Trach., p. 13, 1930.

3. Rocha Lima.-Un Kolle u. Wassermann. III edit., Berlin, 1930, T. VII, p. 1345.

4. Busacca.-Optics R. Concilium Ophtalmol. Madrid, T III, 2-3, December, 1933.

5. A. Cuénod.-Arch. de l'Institut. Pasteur de Tunis, January, 1935. Arch. d'Ophtal., March, 1935.

6. A. Cuénod and R. Nataf.-Arch. d'Ophtal., April, 1935.

7. — Arch. d'Ophtal., March, 1936.

8. - Arch. d'Ophtal., May, 1936.

9. Busacca.-Ann. d'Ocul., July, 1936.

10. v. Szily.-Klin. Monatsbl. f. Augenheilk., 1935.

11. Poleff.-Arch. d'Ophthal., December, 1935

12. Arch. de l'Institut Pasteur de Tunis, March, 1937. Revue Internat. du Trach., April, 1937.

13. Ibid.-Soc. d'Ophtal. de Paris, April, 1937.

\section{ANNOTATION}

\section{"Deuteranopes"}

There has recently been some correspondence in the Times on this subject, which we should have considered more suitable for the "silly season" than for early.spring. It would have fitted in well with such topics of enduring interest as the abolition of capital punishment, of corporal punishment and the old school tie.

One of the correspondents seemed to imagine that all colour blind people are deuteranopes, which is very wide of the mark. One seemed especially pleased to know of this label for his condition. It began with a pathetic wail of a deuteranope about his difficulties in distinguishing the colours of the ordinary penny and halfpenny postage stamps in use in this country at the present time. The deuteranope, more than any other person, is liable to put the wrong stamp on a postcard. But in either case it is to the advantage of the 